\title{
sciendo
}

DOI: $10.2478 /$ jolace-2021-0007

\section{Basic pillars of the concept and strategy of teaching Slovak language and Slovak literature in primary schools with Hungarian as the language of instruction}

\author{
István Szőköl, Andrea Puskás \\ J. Selye University, Komárno, Slovakia \\ szokoli@ujs.sk, puskasa@ujs.sk
}

\begin{abstract}
Slovak language and Slovak literature is a specific subject in schools with Hungarian as the language of instruction and occupies a leading place in the hierarchy of subjects. Its specific role is determined by the fact that Slovak language has the status of a state language in the Slovak Republic, it is the language of the majority, a means of communication, i.e. a tool for communication for citizens of Hungarian nationality with citizens of other nationalities in the Slovak Republic and at the same time it is a second (specific target) language in schools with Hungarian as the language of instruction. Social requirements are taken into account when planning the curriculum and the educational process. Children and pupils of citizens belonging to national minorities and ethnic groups are guaranteed the right to learn the state language. The educational process in schools with the language of instruction of nationalities is carried out in accordance with the instrument of ratification of the European Charter for Regional or Minority Languages. The importance of being able to speak the majority language by members of minorities is supported by a number of European recommendations.

The paper deals with the concept and strategy of teaching Slovak language and Slovak literature as well as its central position: helping the overall personal development of students, acquiring habits of good behaviour, especially in the field of speech, positively influencing the development of language-analogous abilities, the development of feelings connected with the language, creativity and positive attitudes towards Slovak language.

Key words: schools with Hungarian as the language of instruction, teaching process, Slovak language and Slovak literature, concept of teaching, strategy of the teaching process

\section{Introduction}

The initial strategy for teaching the subject Slovak language and Slovak literature in primary schools with Hungarian as the language of instruction (with HLI) is communicative teaching, a communicative approach to the creation of the concept and strategy of teaching.

The key concept for teaching SLSL is communication competence, which means the ability of the participant of communication to understand and create lexically and grammatically correct sentences and the ability to interact in common social situations in accordance with Slovak language standards.

The communicative approach to the creation of the content and process of teaching and mastering the Slovak language means following the principle of the thematic modelling of language and the principle of language transfer through the speech channel of communication, i.e. in the form of dialogues and discussions, while ensuring the necessary conditions for successful communication: communicative situations, sufficient motivation, unambiguous identification and natural semantization of speech.

The principles of communicative teaching require the right proportionality of the process of automation and the cognitive component. In the sense of these principles, the goal, the content and the means of teaching and learning a language is communication.
\end{abstract}


The peculiarities of individual learning come to the foreground, the educational process is differentiated according to the individual abilities and innate preferences of the learner, and the influence on reason and emotions is used.

For the teaching of Slovak language in schools with Hungarian as the language of instruction, the generally valid psychological principles, and the principles of the technology of teaching foreign languages apply. A foreign language teacher influences the pupils' psyche, which determines the methods and forms of teaching with its peculiarities. The subject itself is very closely connected with thinking. The essence of teaching lies in a certain change in thinking itself. When teaching a foreign (non-native) language, the aim is to teach the learners to think in the language they are learning. An important element of the psychological foundations of teaching and learning foreign languages is being aware of the fact that language can be learned in practice, i.e. by natural acquisition in the necessary contact with the target language environment or consciously during lessons in class. The process of acquiring Slovak language in schools with Hungarian as the language of instruction is a deliberate process, because the mother tongue is present in the consciousness of the learners, regardless of whether it is completely excluded from the language learning process or not.

In the teaching of SLSL, similarly to foreign languages, an activity-oriented approach is applied, which takes into account the cognitive, emotional and volitional possibilities, and even the whole repertoire of the learner's abilities. It emphasizes the active and meaningful use of language, which develops listening comprehension, speaking, reading comprehension and writing.

1 General goals of teaching Slovak language and Slovak literature in HL1 schools

The complex goal of SLSL teaching is determined on the one hand by the modernization of SJSL teaching and on the other hand by the demanding requirements of society in terms of political, social and linguistic aspects. This goal includes, above all, practical, active mastery of the language, knowledge of the cultural values of the Slovak nation based on the principle of age adequacy.

In the teaching of SLSL in schools with HLI, general goals are set, namely: to improve learners' awareness of cultural and linguistic diversity within Europe and the world and within individual social environments; to arouse learners' interest in learning another language; to cultivate and strengthen a positive attitude of learners towards learning the Slovak language as $\mathrm{L}_{2}$; to motivate learners to use basic cultural tools for cultivated communication; to gradually distinguish different parts of culture; to develop visual, auditory, linguistic and physical literacy and creativity; to develop learners' awareness of their own cultural identity; to cultivate and strengthen learners' positive relationship and tolerance of the Slovak nation and other ethnic groups; to teach learners to perceive, understand and respect differences and equality; to develop the ability to respect and tolerate the values of other cultures; to develop learners' interest in the cultural and literary heritage of the Slovak nation; to lead learners to understand the importance of cultural and artistic monuments in Slovakia.

The specific goals of Slovak language and Slovak literature in schools with HLI define the acquired competencies of learners in listening and reading comprehension, speaking and writing at individual levels of education, taking into account the language environment of the school, language skills, the acquired language code and the age of the learners. They determine that the learner should be able to recognize the contrasting features of the Hungarian and Slovak alphabet as well as basic linguistic phenomena, know and apply orthoepic, orthographic and grammatical rules necessary for oral and 
written communication in a given developmental period of learners, acquire oral communication language skills, achieve a smooth transition from reproductive to productive forms of communication, conduct oral and written communication in various social situations with adequate knowledge of grammar, solve standard social situations within the frame of certain communication topics appropriate to the age of learners, independently express thoughts in Slovak (orally and in writing), describe their own aesthetic experiences and think critically.

The teaching of SLSL takes into account the fact that language varies with use according to the requirements of the context in which it is used. From this point of view, language is not a neutral tool of thinking. The need and desire to communicate arise in a specific situation, while the form and content of communication are a response to this situation.

According to Alabánová (2005), the goals of teaching Slovak language and Slovak literature in a primary school with Hungarian as the language of instruction can be divided as follows:

A. Productive-receptive (communicative) command of the Slovak language. Objectives formulated in the productive-receptive command of the Slovak language include cognitive, instrumental (tool of further education) and communicative function as the basic functions of teaching Slovak language and literature.

B. Informative aspect, in which, in addition to knowledge of Slovak, knowledge of general educational nature is included.

C. The formative function (development of mental cognitive processes) of teaching Slovak language is related to the following:

- forming an interest in the Slovak language as a second language,

- cultivating and forming a positive attitude to and relationship with the Slovak language,

- developing attitudes and habits to cultivate one's own language,

- developing an aesthetic feeling.

The priority goal of teaching Slovak language and Slovak literature in schools with Hungarian as the language of instruction is to improve learners' communicative competence in the interest of achieving bilingualism, resp. multilingualism at the level of the functional definition of bilingualism, according to which any speaker who uses two languages in his daily linguistic practice is bilingual, regardless of their level of proficiency. This strategic goal at the second stage of primary school and at secondary school is fulfilled if the communicative competence of bilingual speakers is combined with proper mastery and practical use of the rules of using Hungarian and Slovak language and communication in various communicative situations.

The main goal of teaching a subject includes three target components: communicative, cognitive and formative, and thus requires the fulfilment of sub-goals in the communicative, cognitive and formative areas, including sub-goals in the social area.

The specific goals of Slovak language and Slovak literature in schools with Hungarian as the language of instruction are the following:

- to teach learners to recognize the contrasting features of the Hungarian and the Slovak alphabet and basic linguistic phenomena,

- to make learners acquainted with orthoepic, orthographic and grammatical rules necessary for oral and written communication in a given developmental period,

- to develop oral communication language skills of learners, to achieve a smooth transition from a reproductive to a productive form of communication. 


\section{The strategies, methods, teaching techniques, organizational forms of teaching Slovak language and Slovak literature in schools with HLI}

\subsection{Strategies}

Language is dynamic, open and constantly changing, so the methodology of language teaching must not be seen as a set of standardized, accepted procedures and techniques. There are several strategic directions in language teaching.

Specific criteria for classifying teaching strategies in relation to a foreign language:

- the goal of using language strategies in terms of language use - strategies of learning strategies and strategies of language use

- environment - learning strategy and language acquisition strategy,

- form of language support - direct versus indirect,

- speaking skills and language resources,

- linguistic issues,

- success or proficiency in the language.

The proposal of four factors supporting the study of a second language and the formation of bilingualism is one of the most stimulating proposals for improving the formation of bilingualism.

- Organizational factors - in the teaching of the second language L2, it is necessary to provide alternative curricula with a high degree of success and a bilingual teacher with good professional and methodological readiness.

- Affection factors - a favourable learning environment, non-authoritative teaching and internal motivation related to the understanding of educational goals and sympathy for them.

- Factors related to learning - low level of anxiety, high degree of motivation and high self-confidence of the learner (feelings of success).

- Linguistic factors - linguistic-social factors are related to the language and to the social and linguistic environment of the learners. Quality teaching of learners' native language is important, because the use of language in thinking and solving problems in their mother tongue can be transferred to other languages.

A favourable atmosphere in the classroom can be created by the following rules:

- We should insist that learners do not use language and attitudes from television sitcoms in the classroom; create a place where rational human beings work together.

- Learners should feel recognized as people who are important and worth meeting on a regular basis, at least once a week; we should do group activities (intensively at the beginning of the year until mutual trust is built).

- We should not assume that learners come to school with already acquired social and life skills; we should teach them.

Consistently, we should only offer learners a meaningful curriculum that raises their expectations and belief that if we offer them something, they will be able to do it and, most importantly, it is worth paying attention to it and think about it. Social requirements are taken into account when planning the educational process. Children and pupils of citizens belonging to national minorities and ethnic groups are guaranteed the right to learn the state language. The educational process in schools with the language of instruction of nationalities is carried out in accordance with the instrument of ratification of the European Charter for Regional or Minority Languages. The importance of commanding 
the majority language by members of minorities is supported by a number of European recommendations.

In the initial phase of primary school with HLI, a method that models natural communication and stimulates learners' interest in other areas of social life is considered optimal.

In the early stages of the youngest children with a minimum level of language proficiency, it is recommended to use the Total Physical Response method, a foreign language teaching method that uses physical movement in response to a verbal stimulus (based on coordination of speech and activity), thus reducing barriers and reducing the affective filter. In the introductory oral course, it is useful to combine the structural global audio-visual method with the linguistic-motor method, which combines speech activity with movement and has a motivating effect. In the next stage of the acquisition of the Slovak language in the first level of primary school with HLI for the acquisition of reading and writing skills in Slovak, it is appropriate to combine the linguistic-motor method with the reduced direct method. It is desirable to use activating and progressive forms and methods of teaching effectively, ones that support learners' independent cognitive activities as well as their productive and creative thinking. This includes the problem method, the heuristic method, illustrative, practical, situational and staging methods, etc. Intensive language teaching presupposes modern textbooks, combined with up-to-date teaching equipment. At the first level of primary school, enlarged situation images are especially needed.

Therefore, it is necessary to adapt the content, methods, forms but also the pace of teaching to the language skills of the learners with a consistent application of the communicative principle within the components of the school subject.

\subsection{Overview of methods}

\section{Total Physical Response (TPR)}

It is a method of teaching foreign languages that uses physical movement in response to a verbal stimulus, thereby reducing barriers for learners and reducing their affective filter. Author of the theory J. Asher argued that the skill of listening comprehension must be acquired by the learner before learning to speak. The TPR method is based on the coordination of speech and activity, which combines information and skills based on the use of a kinetic-sensory system. This combination of skills allows learners to assimilate information and skills quickly, thus contributing to the high learning motivation of learners. The basic teaching technique is based on the teacher giving orders and physically demonstrating them himself/herself. It uses the target language from the beginning. Children respond to instructions, spoken speech first physically, only when they acquire listening comprehension, they begin to speak spontaneously and without much effort. This delay in speaking until the learner is ready to speak spontaneously reduces stress and strengthens learners' self-confidence and confidence in their abilities.

\section{Structural Global Audio-Visual Method}

This method is based primarily on connecting the situation - context - image - group of words - meaning (the global working in structure). It is based on the thesis that the teaching of foreign languages must be implemented on a situational basis. In addition to influencing hearing and sight simultaneously, it does not practice isolated words, but structured language units. The basic and smallest unit of a structured whole is a sentence. Sentences are chosen as models that can be changed, supplemented, and developed. With this method, the learner gets acquainted with comprehensive expressions as well as the 
rhythm, the intonation and the melody of the Slovak language. It is important to connect the sound with an image; the culmination of the work is the active use and combination of sentence structures.

\section{Linguistic-Motor Method}

It combines verbal, musical and sensory-physical elements of teaching. It develops the learner's visual, auditory and motor memory. The learner has the opportunity to accompany his/her speech in a situational dialogue with natural gestures and facial expressions. Speech is set in a situational context.

\section{Activating methods}

According to Alabánová (2003), these methods are based on inductive procedures, monolingual semantization and prefer spoken language, in which the emphasis is also on the practice of correct pronunciation and intonation. Specific examples are practiced, grammatical phenomena without knowledge of grammatical rules. Inductive procedures are important for the development of thinking, they are concrete, illustrative, and they support and develop the activity and creativity of learners.

\section{Direct Method}

It is basically the teaching of the spoken language through conversation, learning through play and movement. From a methodological aspect, it is based on the principle of imitation of a foreign language environment, situational anchoring of the curriculum, absence of any confrontation with the mother tongue, practice of grammatical phenomena inductively, priorities of oral expression and emphasis on correct orthoepic habits. The acquisition of a second language should be carried out in the same way as in the teaching of the mother tongue. In the process of learning a second language, it does not respect the principle of support provided by the mother tongue at all. When explaining the meaning of words, phrases (even abstract ones), monolingual semantization is applied. Demonstration plays a primary role in this task. The practical goal of this method is the acquisition of living spoken language; it attributes an important role to the practice of pronunciation, the teaching of phonetics through phonetic exercises, and it reduces the role of grammar.

\section{Partially Reduced Direct Method}

This method fully respects the principle of support provided by the mother tongue in the teaching of a second language. This is reflected in the implementation of the introductory oral course, in its preference for the communicative method of teaching (in the choice of topics, in forms and means) and monolingual semantization. The explanation of abstract concepts and grammatical rules is carried out in the mother tongue.

\section{Combined Method}

It places spoken language at the centre of the teaching process, uses a lot of conversation, monolingual semantization to explain concepts, but also uses the mother tongue, especially in the interpretation of abstract concepts and in the teaching of grammar rules. Two-way translation is also used, which actually checks the level of understanding and learners' language skills. 


\section{Communicative Approach or Situational Language Teaching}

A functional approach to language dominates. The method is not narrowly defined but is based on the principle that learning is supported only by those activities which are based on real communication and in which language is used to perform meaningful tasks. Learners learn language as a means of expressing their thoughts, values and judgments, to express the functions that are most closely linked to their communication needs. The method is based on the following principles: a) learners learn to communicate through interaction in the target language, b) authentic texts must be used in teaching, c) it is necessary to create such conditions for learners in the classroom so that they can focus not only on the language but also on the learning process itself, d) learners need to be encouraged to use the language independently in order to gain their own experience, as this experience contributes significantly to increasing the effectiveness of language teaching at school, e) it is necessary to link language learning at school with language activities outside the school and the classroom.

\section{Teaching techniques - Three-level taxonomy of teaching techniques}

In lessons of Slovak language and literature, we recommend using a three-level taxonomy of teaching techniques according to Brown. Teaching techniques are divided into controlled, partially controlled and free, i.e. uncontrolled teaching techniques. In the learning process, it is recommended to vary controlled, partially controlled and uncontrolled teaching techniques, while in the first level of primary school with HLI, partially controlled teaching techniques are preferred.

\section{Controlled techniques}

1. Techniques for introducing the language to the learners, for warming up and relaxing, such as singing, dancing, relaxation techniques, etc.

2. Assignment, introduction of the topic to learners: focusing learners' attention on the goal of the lesson, guiding the situation, questions, highlighting the text in the textbook, sound recording, pictures, maps, etc.

3. Organizational techniques: structuring a lesson or class activity. This also includes the organization of the discipline, the external organization of the class (division of learners into groups, moving furniture, etc.).

4. Explanation of the new topic of the lesson: grammar, lexical, sociolinguistic, pragmatic, resp. other areas of the language.

5. Demonstration of role-plays: demonstrated by the teacher or by prepared learners. This also includes short language models, a brief representation of the linguistic phenomenon (patterns), mini-dialogues or collocations.

6. Presentation of dialogue or narration: for passive reception - reading, listening to an audio recording, etc.

7. Presentation of a dialogue or narration: demonstration of acquired knowledge or learners' prepared texts by literal reproduction, in groups or individually.

8. Reading aloud.

9. Checking learners' work, oral presentations, etc.

10. Questions - answers, speech: activities requiring learners to respond immediately and promptly to questions usually learned with expected sentences and answers. It is recommended to distinguish these questions and responses from those requiring unprepared, unforeseen, free answers and learner responses.

11. Drilling, repetition of model sentences and dialogues, substitution and other mechanical activities. 
12. Translation.

13. Writing by dictation.

14. Copying (from the board, from the textbook, etc.).

15. Identification, noticing: learners select - notice and create or identify specific forms, functions, definitions or focus of a lesson.

16. Recognition: students identify the form, etc. It is actually identification more or less without language production, e.g. learners check paragraphs and parts of texts, draw symbols, sort and organize pictures, etc.

17. Repetition: including repetition in the form of a test.

18. Testing as a form of measuring learners' learning results.

19. Meaningful (not mechanical) drill: drilling activities requiring learners to choose from a variety of information.

\section{Partially controlled techniques}

20. Brainstorming.

21. Storytelling (especially by learners): on the basis of texts, a detailed coherent presentation of a story either by teachers or by learners (it can also overlap with the so-called motivational, introductory techniques or acting out dialogues, short stories). This activity is also suitable for keeping learners' attention, for motivation, etc.

22. Questions and answers, expressions: activities requiring immediate expressions, free answers of learners (for example, when asking questions, the teacher does not know what kind of information the learner has).

23. Chain dialogue, resp. developing a dialogue: according to pictures, postcards, miming, etc.

24. Transfer of information: from one form of oral activity to another, for example writing down the content of the heard text, filling in the gaps of a text or diagram, tables according to oral instructions, etc.

25. Information exchange: tasks requiring two ways of communication, exercises to obtain, gather missing information when one or none of the participants in the communication has the necessary information for meaningful communication.

26. "Immersion" in learning: a brief summary, a summary of the lessons, the main points of the text (tasks, etc.) that the learners have to learn or apply in practice.

27. Presentation of a story or explanation of a stimulus. This activity differs from the development of a dialogue, respectively chain dialogue, in that it does not require any other stimulus.

28. Preparation: learners' learning, quiet reading, individual work with a textbook or workbook, preparation for presenting in pairs, preparation for listening comprehension, etc.

29. Free, uncontrolled techniques.

30. Role-play: a relatively independent, free activity. It is not identical with the development of a dialogue, resp. with chain dialogue. (In fact, chain dialogues require only minimal independent learner activity, especially when starting a dialogue.)

31. Games: Various forms of active language games.

32. Papers: on the basis of a textbook, listening, research, elaboration of a work plan without stimulus by the teacher, according to the interest of learners.

33. Problem solving.

34. Dramatization: planned dramatized presentation of a play, story, etc. 
35. Simulation: imitation of life situations, activities requiring interaction between groups of learners and individuals.

36. Interview.

37. Discussion.

38. Composition: elaboration of the structure of a paper, written development of the topic, story, etc.

39. "Apropos": a conversation or other socially oriented interaction, according to the narration of the teacher, the learners or a visitor about the most important and current topics in life.

\section{Organizational forms}

Out of the organizational forms of work, in the first level of primary school, frontal and individual work with learners is recommended and pair work to a lesser extent, however, in the second level of primary school and in secondary schools it is recommended to use group work and pair work to a greater extent.

Proven forms of learners' activities outside the classroom or school include interest groups, various discussions, visits to the theatre and the cinema, exhibitions, correspondence, friendships with students of Slovak nationality, spending time in a Slovak language environment, joint swimming and skiing courses, entering the "Learn Slovak" competition as well as other competitions in Slovak language.

Various student camps and summer language courses provide useful opportunities for developing speaking skills. The overall level of Slovak language can also be positively influenced by the radio and television through suitable and engaging programmes.

\section{Conclusion}

Social changes also affect the work of the school and place high social demands on learners' active mastery of the Slovak language. The social requirement of mastering the state language is valid for all types of schools; however, the results of the educational process do not always correspond to the ideas about the level of the Slovak language proficiency of learners. The level of Slovak language proficiency for some learners is not proportional to the effort and the amount of time spent on achieving the goal. Despite innovations in the teaching of Slovak language and Slovak literature and the results achieved so far, it has not yet been achieved to develop the required communicative competence for some learners.

In order to improve the teaching of SLSL in primary schools with HLI, it is recommended to ensure regular education of teachers of schools with HLI (continuous education, lectures, seminars, workshops) focused on methodology, conversation and specific issues of teaching Slovak language and Slovak literature. The proposal of the concept of teaching Slovak language and Slovak literature in schools with Hungarian as the language of instruction follows the theory of teaching this subject, crystallized during its more than ninety years of existence and also includes the latest knowledge in teaching languages (foreign and native language) both in our country and abroad.

\section{References}

Alabánová, M. (2005). Slovenský jazyk a literatúra v menšinových školách. Nitra: Univerzity Konštantína Filozofa.

Alabánová, M. (2000). Antológia zo slovenskej detskej literatúry pre štúdium učitel'stva 1. stupňa ZŠ s vyučovacím jazykom mad'arským. Nitra: Univerzita Konštantína Filozofa. 
Bernáthová, A. (2003). Stav a problémy vyučovania slovenského jazyka a literatúry na 2. stupni ZŠ s vyučovacím jazykom mad'arským na rozhraní tisícročia. Bratislava: ŠPÚ.

Döményová, A. \& Halászová, A. (2014). Vybrané údaje z výskumu Štátneho pedagogického ústavu Sledovanie úrovne vyučovania slovenského jazyka v základných a stredných školách s vyučovacím jazykom mad’arským. In: Zborník medzinárodnej vedeckej konferencie Univerzity J. Selyeho 2014: Vzdelávanie a veda na začiatku XXI. Storočia. Komárno: UJS, pp. 114 - 137.

Halászová, A. (2002). Zhodnotenie súčasného stavu úrovne vyučovania slovenského jazyka na 1. stupni ZŠ s VJM. Bratislava: ŠPÚ.

Horváthová, K. (2011). Súčasné požiadavky na proces riadenia škôl a prípravu školských manažérov v Slovenskej republiky. In: Otázky koncepcie prípravy riadiacich zamestnancov škôl. Nitra: Univerzita Konštantína Filozofa, pp. 9-47.

Kalhous, Z. \& Obst, O. (2002). Školní didaktika. Praha: Portál.

Koncepcia vyučovania cudzích jazykov v základných a stredných školách (2007). Bratislava: ŠPÚ.

Pokrivčáková, S. \& Pokrivčák, A. (2016). Teaching Slovak language and literature in Slovakia. In Pieniążek, M. \& Štěpáník, S. (Eds.), Teaching of National Languages in the V4 Countries (pp. 135 - 170). Prague: Charles University.

Prokypčáková, K., Malá, D., \& Porubská, G. (2006). Celoživotné vzdelávanie ako cesta ku znalostnej spoločnosti (skúsenosti PF UKF v Nitre). Bratislava: Eruditio.

Průcha, J. (1997). Moderní pedagogika. Praha: Portál.

Šenkár, P. (2019). Lowland Slovak youth literature and its interpretational and educational aspects (within and outside the school). Journal of Language and Cultural Education, 7(3), 97-114. DOI 10.2478/jolace-2019-0023

Szarka, K. (2017). Súčasné trendy školského hodnotenia: Koncepcia rozvíjajúceho hodnotenia. Komárom: Kompress.

Štátny vzdelávací program pre 1. stupeň základnej školy v Slovenskej republike: ISCED 1 - primárne vzdelávanie. Available on: http://www.statpedu.sk/files/documents/svp/1stzs/isced1/isced1_spu_uprava.pdf

Tóblová, E., Pisoňová, M., \& Bírová, J. (2017). The analysis of educational needs of managing teaching staff in schools in the Slovak Republic. Modern Journal of Language Teaching Methods, 7(5), 11-17.

\section{Contacts}

Dr. habil. Ing. István Szőköl, PhD., Ing-Paed IGIP

Faculty of Education, J. Selye University

Department of Pedagogy

Bratislavská cesta 3322

94501 Komárno, Slovakia

szokoli@ujs.sk

PaedDr. Andrea Puskás, PhD.

Faculty of Education, J. Selye University

Department of English Language and Literature

Bratislavská cesta 3322

94501 Komárno, Slovakia

puskasa@ujs.sk 